\title{
EVALUASI NILAI BIOLOGIS BAHAN KERING DAN BAHAN ORGANIK PAKAN LENGKAP BERBASIS TEBON JAGUNG PADA SAPI PERAH
}

\author{
Meylin Manganang, Ronny A.V. Tuturoong*, Abraham F. Pendong, \\ Merci R. Waani
}

Fakultas Peternakan Universitas Sam Ratulangi Manado, 95115

\begin{abstract}
ABSTRAK
Penelitian ini bertujuan untuk mengetahui konsumsi dan kecernaan bahan kering dan bahan organik pakan lengkap berbasis tebon jagung. Penelitian ini menggunakan 14 ekor sapi FH dengan berat badan $300-400 \mathrm{~kg}$. Pakan perlakuan, terdiri dari $\mathrm{Ra} \quad(30 \%$ konsentrat $+70 \%$ tebon jagung); $\mathrm{Rb}(30 \%$ konsentrat $+35 \%$ tebon jagung $+35 \%$ rumput raja). Percobaan ini diarahkan menggunakan analisis statistik uji - $\mathrm{t}$ dua contoh dengan ragam tidak sama (t-test two sample assuming unequal varience). Variabel yang diamati adalah konsumsi bahan kering dan bahan organik serta kecernaan bahan kering dan bahan organik. Hasil analisis menunjukkan konsumsi bahan kering dan bahan organik pakan Ra berbeda tidak nyata $(\mathrm{P}>0,05)$ dengan perlakuan $\mathrm{Rb}$. Kecernaan bahan kering perlakuan $\mathrm{Rb}$ berbeda sangat nyata $(\mathrm{P}<0,01)$, dengan perlakuan $\mathrm{Ra}$ dan kecernaan bahan organik perlakuan $\mathrm{Rb}$ berbeda nyata $(\mathrm{P}<0,05)$ dengan perlakuan Ra. Dapat disimpulkan bahwa pakan yang menggunakan konsentrat, tebon jagung dan rumput raja memperoleh hasil kecernaan bahan kering dan bahan organik yang terbaik.
\end{abstract}

Kata kunci: Tebon jagung, konsumsi, kecernaan, bahan kering, bahan organik

*Korespondensi (corresponding author ): Email: ronny.tuturoong@yahoo.com

\section{ABSTRACT}

EVALUATION

OF BIOLOGICAL VALUE OF DRY MATTER AND ORGANIC MATTER COMPLETE FEED BASED ON CORN FORAGE IN DAIRY COWS. This aim of this study was to determine intakes and digestibility of the dry matter and organic matter of complete feed based on corn forage. $14 \mathrm{FH}$ cows weighing $300-400 \mathrm{~kg}$ were used in this research. The feed treatments consist of $\mathrm{Ra}(30 \%$ concentrate $+70 \%$ corn forage), and $\mathrm{Rb}(30 \%$ concentrate $+35 \%$ corn forage $+35 \%$ king grass). This experiment arranged in a statistical method of t-test two sample assuming unequal variance. The variables observed were intakes and digestibilities of both dry matter and organic. The results shows that the intakes of both dry matter and organic matter in the $\mathrm{Ra}$ were not significantly different from the $\mathrm{Rb}(\mathrm{P}>$ 0.05). The dry matter digestibility of $\mathrm{Rb}$ were highly significant different from $\mathrm{Ra}$ $(\mathrm{P}<0.01)$, as well as organic matter digestibility of $\mathrm{Rb}$ was also significantly different from $\operatorname{Ra}(\mathrm{P}<0.05)$. It is concluded that complete feed consisting of concentrate, corn forage and king grass was obtained the best digestibilities of both dry matter and organic matter.

Keywords: Corn forage, intake, digestibility, dry matter, organic matter 


\section{PENDAHULUAN}

Sapi perah merupakan ternak penghasil susu untuk mencukupi kebutuhan susu dunia bila dibandingkan dengan ternak penghasil susu yang lain, sehingga dalam pemeliharaanya selalu diarahkan pada peningkatan produksi susu (Al-amin et al., 2017). Upaya untuk meningkatkan produksi peternakan secara cepat hanya dapat dicapai apabila ditunjang dengan penyediaan pakan yang berkualitas. Produksi ternak yang tinggi perlu didukung oleh ketersediaan pakan hijauan yang cukup dan kontinyu (Suryana, 2009). Salah satu sumber utama pakan hijauan adalah berasal dari rumput. Rumput yang sangat potensial dan sering diberikan pada ternak ruminansia adalah rumput raja (Pennisetum purpupoides). Rumput raja (Pennisetum purpupoides) adalah jenis rumput hasil persilangan antara rumput gajah (Pennisetum purpureum) dengan rumput barja (Pennisetum thypoides). Rumput raja adalah tanaman tahunan (perennial), tumbuh tegak membentuk rumpun (Suyitman, 2014).

Tebon jagung merupakan pakan ruminansia yang kualitasnya baik. Tebon jagung mengandung banyak karbohidrat terlarut yang akan mendukung perkembangbiakan mikroorganisme (Rif'an, 2009). Tebon jagung adalah seluruh tanaman jagung termasuk batang, daun dan buah jagung muda yang umumnya dipanen pada umur tanaman 4565 hari (Soeharsono dan Sudaryanto,2006) dengan kandungan nutrisi tebon jagung yaitu, PK 12,06\%, SK 25,2\%, Ca 0,28\%, P 0,23\% (Erna dan Sarjiman, 2007).

Kecernaan merupakan suatu rangkaian proses yang terjadi dalam alat pencernaan sampai terjadinya penyerapan (Wahyuni et al., 2014). Daya cerna dapat menjadi ukuran tinggi rendahnya nilai gizi suatu bahan makanan. Pada umumnya pakan dengan kandungan zat-zat makanan yang dapat dicerna tinggi, maka akan tinggi pula gizinya. Menurut Astuti et al. (2009), nilai kualitas suatu bahan pakan dapat diketahui melalui percobaan kecernaan pada ternak.

Kecernaan bahan kering merupakan salah satu indikator untuk menentukan kualitas ransum. Semakin tinggi kecernaan bahan kering maka semakin tinggi pula peluang nutrisi yang dapat dimanfaatkan ternak untuk pertumbuhannya (Afriyanti, 2008). Kecernaan bahan organik menggambarkan ketersediaan nutrien dari pakan. Kecernaan bahan organik dalam saluran pencernaan ternak meliputi kecernaan zat-zat makanan berupa komponen bahan organik seperti karbohidrat, protein, lemak dan vitamin.

Itulah sebabnya dilakukan suatu penelitian yang bertujuan untuk mengevaluasi nilai konsumsi dan 
kecernaan bahan kering dan bahan orgnanik pakan lengkap berbasis tebon jagung pada sapi perah.

\section{MATERI DAN METODE PENELITIAN}

Penelitian ini dilaksanakan di Unit Pelaksana Teknis Daerah (UPTD) Pembibitan Ternak dan Hijauan Pakan Provinsi Sulawesi Utara, Tampusu Kecamatan Remboken Kabupaten Minahasa.

Penelitian ini menggunakan 14 ekor sapi FH, berumur $7-8$ tahun dengan bobot badan antara $300-400 \mathrm{~kg}$. Pakan yang digunakan adalah tebon jagung, rumput raja dan konsentrat. Bahan pakan penyusun konsentrat adalah jagung, dedak halus, bungkil kedelei, bungkil kelapa, tepung ikan, premix (suplemen, vitamin, mineral) dan garam. Penggunaan 30\% konsentrat dan $70 \%$ pakan hijauan, didasarkan pada kebutuhan ternak sapi perah dengan bobot badan rata-rata $300 \mathrm{~kg}$, dengan kebutuhan bahan kering 7,5 kg (Dairy NRC, 2001).

Kandang yang digunakan adalah kandang individual sebanyak 14 kandang yang dilengkapi dengan tempat pakan dan tempat minum.

\section{Metode Penelitian}

Penelitian ini menggunakan metode eksperimen. Penelitian ini terdiri dari 2 perlakuan dan 7 ulangan, dimana penempatan perlakuan dilakukan secara acak. Perlakuan terdiri dari $\mathrm{Ra}=30 \%$ konsentrat $+70 \%$ tebon jagung; $\mathrm{Rb}=30 \%$ konsentrat $+35 \%$ tebon jagung $+35 \%$ rumput raja. Data yang diperoleh dianalisis dengan menggunakan Uji $\mathrm{T}$ dua contoh dengan ragam tidak sama ( $t$-test two sample assuming unequal varience) (Snedecor and Cochran, 1989; Derrick, et al. 2017).

\section{Tatalaksana Penelitian}

Pelaksanaan penelitian dibagi menjadi 3 tahap yaitu:

1. Tahap Adaptasi

Pada tahap ini, dilakukan adaptasi pakan selama 7 hari. Adaptasi dilakukan dengan tujuan membiasakan ternak mengkonsumsi pakan perlakuan dan mengetahui konsumsi pakan bebasnya, dimana dilakukan pengambilan data konsumsi. Pakan diberikan secara ad libitum serta air minum disediakan setiap saat. Rumput raja dan tebon jagung dicacah (chopper) terlebih dahulu dengan ukuran \pm $5 \mathrm{~cm}$. Konsumsi ternak dihitung dari kemampuan ternak mengkonsumsi bahan kering.

2. Tahap pra-koleksi

Tiga hari sebelum pengambilan data 
Tabel 1. Komposisi nutrien bahan pakan penelitian

\begin{tabular}{lccc}
\hline \multirow{2}{*}{ Nutrien } & Konsentrat & Tebon Jagung* & Rumput Raja** $^{*}$ \\
\cline { 2 - 4 } & \multicolumn{3}{c}{} \\
\hline Bahan Kering & 87,93 & 19,73 & 20,30 \\
Bahan Organik & 78,82 & 87,94 & 89,08 \\
Protein Kasar & 16,65 & 10,90 & 9,52 \\
Lemak Kasar & 10,75 & 2,17 & 3,14 \\
Serat Kasar & 11,23 & 33,21 & 31,26 \\
NDF & 27,23 & 69,81 & 73,52 \\
ADF & 14,39 & 40,20 & 44,49 \\
Ca & 0,73 & 0,39 & 0,35 \\
P & 1,82 & 0,23 & 0,28 \\
Abu & 9,11 & 7,67 & 9,38 \\
BETN & 40,48 & 46,05 & 44,98 \\
Energi Bruto (Kkal) & 3708,89 & 3791,00 & 3375,00 \\
\hline
\end{tabular}

Sumber : *) Menurut Tulung et al. (2020)

**) Lab. Nutrisi dan Makanan Ternak Fak. Peternakan UB (2019)

Tabel 2. Bagan perlakuan dan komposisi nutrient

\begin{tabular}{lcc}
\hline \multirow{2}{*}{ Bahan Pakan (\%) } & \multicolumn{2}{c}{ Perlakuan } \\
\cline { 2 - 3 } & $\mathrm{Ra}$ & $\mathrm{Rb}$ \\
\hline Konsentrat & 30 & 30 \\
Tebon Jagung & 70 & 35 \\
Rumput Raja & 0 & 35 \\
\hline Total & 100 & 100 \\
\hline Komposisi Nutrien (\%) & & \\
Bahan Kering & 40,18 & 38,34 \\
Bahan Organik & 85,2 & 85,59 \\
Protein Kasar & 12,63 & 12,13 \\
Lemak Kasar & 4,73 & 5,1 \\
Serat Kasar & 26,16 & 25,91 \\
NDF & 57,03 & 58,22 \\
Abu & 8,1 & 8,69 \\
BETN & 44,37 & 44 \\
Energi Bruto (Kkal) & 3766 & 3620 \\
\hline
\end{tabular}

Keterangan : Komposisi nutrien dihitung berdasarkan Tabel 1. 
koleksi, dilakukan pembatasan pemberian pakan sebanyak $80 \%$ dari rataan konsumsi pakan. Pembatasan pakan dilakukan agar pakan yang diberikan dapat dikonsumsi secara keseluruhan dan tidak tersisa.

3. Tahap koleksi data

Pengukuran kecernaan ini berdasarkan metode koleksi total. Pada tahap ini, pakan tetap diberikan sebanyak $80 \%$. Feses ditimbang setiap defikasi dan diambil sampel 5\% untuk analisis. Pengumpulan feses dilakukan selama 5 hari begitu juga dengan pengambilan sampel pakan. Sampel pakan dan feses dianalisis di laboratorium. Analisis kecernaan bahan kering dan bahan organik dilakukan sesuai pentunjuk proksimat.

\section{Variabel}

1. Konsumsi BK : BK ransum yang diberikan dikurangi $\mathrm{BK}$ ransum yang tersisa.

2. Konsumsi BO : $\mathrm{BO}$ ransum yang diberikan dikurangi BO ransum yang tersisa.

\section{Kecernaan BK}

$\mathrm{KcBK}=\frac{\text { konsumsi } B K-B K \text { feses }}{\text { konsumsi } B K} \times 100 \%$

\section{Kecernaan BO}

$\mathrm{KcBO}=\frac{\text { Konsumsi } B O-\text { BO feses }}{\text { Konsumsi } B O} \times 100 \%$

\section{HASIL DAN PEMBAHASAN}

Data hasil penelitian tentang evaluasi nilai biologis bahan kering dan bahan organik pakan lengkap berbasis tebon jagung pada sapi perah dapat dilihat pada Tabel 3.

\section{Konsumsi Bahan Kering}

Rerata konsumsi bahan kering pada penelitian ini adalah 7529,83 gram/ekor/hari pada perlakuan $\mathrm{Ra}$ dan 7811,14 gram/ekor/hari pada perlakuan RB. Hasil analisis uji $\mathrm{T}$ menunjukkan bahwa perlakuan memberikan pengaruh yang berbeda tidak nyata $(\mathrm{P}>0,05)$ terhadap konsumsi bahan kering pada sapi perah. Rerata konsumsi bahan kering pada penelitian ini lebih tinggi dari yang dilaporkan oleh Tuwaidan et al. (2015) yaitu 2018,60 - 3207,32 gram/ekor/hari dengan menggunakan jerami jagung manado kuning dan jerami jagung hibrida pada ternak sapi PO. Perbedaan Jumlah konsumsi bahan kering diduga, disebabkan perbedaan komposisi nutrien pakan. Parakkasi (1999) bahwa konsumsi bahan kering dipengaruhi oleh beberapa faktor antara lain yaitu berat badan, umur status fisiologis, dan faktor makanan seperti sifat fisik serta komposisi kimia ransum. 
Tabel 3. Rerata Kecernaan Bahan Kering Dan Bahan Organik Pakan Lengkap Berbasis Tebon Jagung

\begin{tabular}{lcc} 
Parameter & \multicolumn{2}{c}{ Perlakuan } \\
\cline { 2 - 3 } & $\mathrm{Ra}$ & $\mathrm{Rb}$ \\
\hline Konsumsi bahan kering (gram/ekor/hari) & 7529,83 & 7811,14 \\
Konsumsi bahan organik (gram/ekor/hari) & 5166,25 & 5121,69 \\
Kecernaan bahan kering (\%) & $76,06^{\mathrm{a}}$ & $81,19^{\mathrm{b}}$ \\
Kecernaan bahan organik (\%) & $68,32^{\mathrm{a}}$ & $72,60^{\mathrm{b}}$ \\
\hline
\end{tabular}

Keterangan: Superskrib yang berbeda pada baris yang sama menunjukkan perbedaan yang nyata $(\mathrm{P}<0,01)$.

\section{Konsumsi Bahan Organik}

Rerata konsumsi bahan organik pakan lengkap berbasis tebon jagung pada penelitian ini adalah 5166,25 gram/ekor/hari pada perlakuan $\mathrm{Ra}$ dan 5121,69 gram/ekor/hari pada perlakuan $\mathrm{Rb}$. Hasil analisis uji $\mathrm{T}$ menunjukkan bahwa perlakuan memberikan pengaruh berbeda tidak nyata $(\mathrm{P}>0,05)$ terhadap konsumsi bahan organik pada sapi perah $\mathrm{FH}$.

Konsumsi bahan organik dalam penelitian ini sejalan dengan konsumsi bahan kering. Hal ini sesuai dengan pendapat Sondakh et al. (2018) menyatakan bahwa tinggi rendahnya konsumsi bahan organik dipengaruhi konsumsi bahan kering.

Rerata konsumsi bahan organik pada penelitian ini lebih rendah dari yang dilaporkan oleh Cahyono et al. (2015) yaitu 5980-6300 gram/ekor/hari dengan menggunakan pakan rumput alam dan konsentrat PUFA pada ternak sapi perah laktasi, perbedaan hasil penelitian kemungkinan disebabkan karena perbedaan kandungan nutrien pakan perlakuan. Menurut Thomaszewska et al. (1993) disitasi oleh Thomas et al. (2014) menyatakan bahwa tingkat konsumsi sangat dipengaruhi oleh koefisisen cerna, kualitas pakan, fermentasi dalam rumen serta status fisiologi ternak.

\section{Kecernaan Bahan Kering}

Rerata kecernaan bahan kering (Tabel 3) pada penelitian ini adalah $76,06 \%$ pada perlakuan $\mathrm{Ra}$ dan $81,19 \%$ pada perlakuan Rb. Hasil analisis Uji $\mathrm{T}$ menunjukkan bahwa kecernaan bahan kering perlakuan $\mathrm{Rb}$ berbeda sangat nyata ( $\mathrm{p}<0,01)$ dengan Ra. Perlakuan $\mathrm{Rb}$ lebih tinggi dari Ra. Menurut Yusmadi (2008) semakin tinggi persentase kecernaan bahan kering suatu bahan pakan, menunjukkan bahwa semakin tinggi pula kualitas bahan pakan tersebut. Kecernaan yang 
mempunyai nilai tinggi mencerminkan besarnya sumbangan nutrien tertentu pada ternak, sementara itu pakan yang mempunyai kecernaan rendah menunjukkan bahwa pakan tersebut kurang mampu menyuplai nutrien untuk hidup pokok maupun untuk tujuan produksi ternak. Tillman et al. (1998) menyatakan bahwa faktor yang mempengaruhi tingkat kecernaan bahan kering salah satunya adalah jumlah bahan kering yang dikonsumsi karena aktivitas mikroba mengikuti bahan pakan yang dikonsumsi

Tingginya kecernaan bahan kering pada perlakuan $\mathrm{Rb}$ dibandingkan perlakuan Ra diduga disebabkan karena kandungan bahan kering dalam pakan. Pada Tabel 2 terlihat bahwa perlakuan $\mathrm{Rb} 38,34 \%$ lebih rendah dibandingkan dengan perlakuan $\mathrm{Ra}$ 40,18\%. Rendahnya kandungan bahan kering pada perlakuan $\mathrm{Rb}$ dapat menyebabkan peningkatan daya cerna bahan kering $\mathrm{Rb}$ oleh karena adanya efek asosiatif nutrien dari bahan pakan perlakuan. Menurut Tuturoong et al. (2014) menyatakan bahwa daya cerna campuran bahan pakan tidak selalu sama dengan ratarata daya cerna komponen bahan-bahan yang menyusunnya, hal ini disebabkan adanya efek asosiasi pakan.

Rerata kecernaan bahan kering pada penelitian ini lebih tinggi dibanding hasil penelitian yang dilaporkan oleh Belo et al. (2018) yaitu 67,51\%-72,78\% dengan menggunakan beberapa jenis limbah pertanian dan rumput lapang pada ternak sapi PO dan hasil penelitian Nasriya et al. (2016) yaitu sebesar 56,27\% - 59,48\% dengan menggunakan rumput raja (Pennisetum Purpupoides) dan tebon jagung terhadap kecernaan bahan kering dan bahan organik pada sapi PO pedet jantan. Menurut Suardin et al. (2014) bahwa kecernaan pakan dipengaruhi oleh perlakuan terhadap pakan (pengolahan, penyimpanan dan cara pemberian) jenis, jumlah dan komposisi pakan yang diberikan pada ternak.

\section{Kecernaan Bahan Organik}

Rerata Kecernaan bahan organik (Tabel 3) pada penelitian ini adalah $68,32 \%$ pada perlakuan $\mathrm{Ra}$ dan $72,60 \%$ pada perlakuan Rb. Hasil analisis Uji $\mathrm{T}$ menunjukkan bahwa kecernaan bahan organik pakan perlakuan memberikan pengaruh yang berbeda nyata $(\mathrm{P}>0.05)$. Kecernaan bahan organik dalam penelitan ini mengikuti kecernaan bahan kering. Setiyaningsih et al. (2012) mengatakan bahwa bahan organik merupakan komponen dari bahan kering sehingga faktor-faktor yang mempengaruhi tinggi rendahnya kecernaan bahan kering akan mempengaruhi tinggi rendahnya kecernaan bahan organik dalam suatu pakan. Hal ini terjadi karena kecernaan bahan organik ini sejalan dengan kecernaan bahan kering, ini 
disebabkan karena bahan organik tersebut merupakan bagian dari bahan kering (Andayani, 2010).

Rerata kecernaan bahan organik pada penelitian ini lebih tinggi dibanding hasil penelitian yang dilaporkan oleh Christiyanto et al. (2005) sebesar 72,23\%$74,74 \%$ yang menggunakan pakan basal rumput raja pada sapi perah dan hampir sama dengan yang dilaporkan oleh Nasriya (2016) yaitu sebesar $87,64 \%$ - 88,72\% yang menggunakan rumput raja dan tebon jagung pada ternak sapi PO pedet jantan.

Perbedaan nilai kecernaan bahan organik tersebut mungkin sebabkan oleh perbedaan komposisi pakan. Kecernaan bahan pakan dipengaruhi oleh beberapa faktor antara lain komposisi kimia bahan pakan, jumlah pakan yang dikonsumsi ternak, frekuensi pemberian pakan, bentuk fisik pakan, jenis pakan, umur tanaman, temperatur lingkungan, spesies, umur ternak, keragaman antara individu ternak dan aktivitas mikroba (Nasriya, 2016).

\section{KESIMPULAN}

Kesimpulan dari hasil penelitian ini adalah kecernaan bahan kering dan bahan organik pakan lengkap yang terdiri dari konsentrat, tebon jagung dan rumput raja lebih tinggi dibanding pakan lengkap yang terdiri dari konsentrat dan tebon jagung.

\section{DAFTAR PUSTAKA}

Afriyanti, M. 2008. Fermentabilitas dan kecernaan in vitro ransum yang diberi kursin bungkil biji jarak pagar (Jatropha curcus L.) pada ternak sapid an kerbau. Skripsi Fakultas Peternakan, Institut Pertanian Bogor, Bogor.

AL-amin, A. F., M. Hartono dan Sri Suharyati. 2017. Faktor-faktor yang mempengaruhi calving interval sapi perah pada peternakan rakyat di beberapa Kabupaten/Kota Provinsi Lampung. Jurnal Penelitian Peternakan Indonesia Vol. 1(1): 33-36. 2017

Andayani, J. 2010. Evaluasi kecernaan in vitro bahan kering, bahan organic dan protein kasar penggunaan kulit buah jagung amoniasi dalam ransum ternak sapi. Jurnal ilmiah ilmu peternakan. Vol. XIII(5): 252259

Astuti, A., A. Agus, S. P. S. Budhi. 2009. Pengaruh penggunaan high quality feed supplement terhadap konssumsi dan kecernaan nutrien sapi perah awal laktasi. Buletin Peternakan 33(2): 81-87.

Belo, S., R. Tuturoong, dan K. Maaruf. 2018. Kecernaan bahan kering dan bahan organik pakan yang mendapatkan suplementasi urea molasses multinutrient blok (UMMB) dari beberapa jenis limbah pertanian dan rumput lapang. Zootec 38(2): 329-336.

Cahyono, B. D., E. Sulistyowati dan I. Badarina. 2015. Kecernaan nutrisi konsentrat PUFA yang mengandung curmiyeast pada 
sapi perah laktasi. Jurnal sain peternakan Indonesia 10 (1): 5970 .

Christiyanto, M., R. Utomo, M. Soejono, H. Hartadi, dan B.P. Widyobroto. 2005. Konsumsi dan kecernaan nutrient ransum yang berbeda perekusor protein-energi dengan pakan basal rumput raja pada sapi perah. J. Indo. Trop. Anim. Agric. 30(4): 242-247.

Derrick, B., B. Russ, D. Toher, dan P. White. 2017. Test statistics for the comparison of means for two samples that include both paired and independent observations. Journal of Modern Applied Statistical Methods 16(1): 137157.

Erna, W. dan Sarjiman, 2007. Budidaya hijauan pakan bersama tanaman pangan sebagai upaya penyediaan hijauan pakan di lahan sempit. Jurnal Peternakan dan Lingkungan. Vol 7: 134-141

Nasriya., R. Tuturoong, Ch. Kaunang, S.S. Malalantang, dan M. M. Tindangan. 2016. Pengaruh pemberian rumput raja (Pennisetum Purpupoides) dan tebon jagung terhadap kecernaan bahan kering dan bahan organik pada sapi PO pedet jantan. Zootec 36(2): 387-394.

National Research Council. 2001. Nutrient Requirements of Dairy Cattle, $7^{\text {th }}$ Rev. Ed. Washington, D.C.: National Academy Press.

Parakkasi, A. 1999. Ilmu Nutrisi dan Makanan Ternak Ruminansia. Universitas Indonesia Press. Jakarta.

Pramono, A., A. Yusuf, S. D. Widyawati dan H. Hartadi. 2018. Pengaruh suplementasi lemak terproteksi terhadap konsumsi dan kecernaan nutrien sapi perah friesian Holstein. Jurnal sains peternakan 16(1) : 34-39.

Rif'an, M. 2009. Pengaruh Lama Fermentasi Pakan Komplit dan Silase Tebon Jagung Terhadap Perubahan $\mathrm{Ph}$ dan Kandungan Nutrien. Skripsi. Jurusan nutrisi dan Makanan Ternak. Fakultas Peternakan. Universitas Brawijaya. Malang.

Setiyaningsi, K. D., M. Christiyanto, dan Sutarno. 2012. Kecernaan bahan kering dan bahan organik secara in vitro hijauan Desmodium cinereum pada berbagai dosis pupuk organik cair dan jarak tanam. J. Animal Agriculture 1(2): 51-63.

Soeharsono., dan B. Sudaryanto. 2006. Tebon jagung sebagai sumber hijauan pakan ternak strategis di lahan kering kabupaten gunung kidul. Prosiding. Lokakarya Nasional Jejaring Pengembangan Sistem Integrasi Jagung Sapi. Puslitbang Peternakan, Bogor. hlm. $136-$ 141.

Sondakh, E. H. B., M.R. Waani, J.A.D. Kalele, and S.C. Rimbing. 2018. Evaluation of dry matter digestibility and organic matter of in vitro unsaturated fatty acid based ration of ruminant. International J. Current Adv. Res. 7(6): 1358213584.

Suardin., N. Sadiah dan R. Aka. 2014 Kecernaan bahan kering dan bahan organik campuran campuran rumput mulato (brachiria hybrid.cv mulato) 
dengan jenis legum berbeda menggunakan cairan rumen sapi. Jitro Vol 1(1): 16-22.

Suryana. 2009. Pengembangan usaha ternak sapi potong berorientasi agribisnis dengan pola kemitraan. Jurnal Litbang Pertanian 28 (1): 29 - 36.

Suyitman, S. 2014. Produktivitas rumput raja (Pennisetum Purpupoides) pada pemotongan pertama menggunakan beberapa sistem pertanian. Jurnal Peternakan Indonesia 16(2): 119-127.

Thomas, J. V. S., M. Tafsin, A. H. Daulay. 2014. Kercernaan bahan kering dan bahan organik ransum yang mengandung pelepah daun kelapa sawit dengan perlakuan fisik, kimia, biologis dan kombinasinya pada domba. Jurnal peternakan integrative 3(1): 62-70.

Tillman, A. D., H. Hartadi, S. Reksohadiprojo, S. Prawirokusumo dan S. Lebdosoekojo. 1998. Ilmu Makanan Ternak Dasar. Edisi Keenam. Gadjah Mada University Press. Yogyakarta.

Tulung, Y. L. R., A. F. Pendong, B. Tulung. 2020. Evaluasi nilai biologis pakan lengkap berbasis tebon jagung dan rumput campuran terhadap kinerja produksi sapi Peranakan Ongole (PO). Zootec 40(1): 363-379.

Tuturoong, R. A. V, Soebarindo, Hartutik, dan Ch. Kaunang. 2014. Evaluasi Nilai Nutrisi Rumput Benggala Teromoniasi dan Ampas Sagu Terfermentasi Dalam Pakan Komplit Terdahap Penampilan Kambing Kacang. Disertasi.
Fakultas Peternakan Universitas Brawijaya. Malang.

Tuwaidan, N. W. H., M. R. Waani., Rustandi dan S. S. Malalantang. 2015. Konsumsi dan kecernaan jerami jagung Manado kuning dan jerami jagung hibrida jaya 3 pada sapi PO. Zootec 35(2): 328334.

Wahyuni, I.M.D., A. Muktiani, dan M. Christiyanto. 2014. Kecernaan bahan kering dan bahan organik dan degradabilitas serat pada pakan yang disuplementasi tanin dan saponin. Jurnal Agripet Vol 2(2): 115-124.

Yusmadi. 2008. Kajian Mutu Dan Palatabilitas Silase Dan Hay Ransum Komplit Berbasis Sampah. Tesis. Institut Pertanian Bogor.. 